\section{AB017. Increased dendritic cells and IFN-beta and MxA protein expression in spongiotic dermatitis differentiates dermatomyositis from eczema}

\author{
Majid Zeidi ${ }^{1,2 \#}$, Kristen L. Chen ${ }^{1,2 \#}$, Basil Patel ${ }^{1,2}$, \\ Rachel Lim ${ }^{1}$, Victoria P. Werth ${ }^{1,2}$ \\ ${ }^{1}$ Department of Dermatology, Perelman School of Medicine at the \\ University of Pennsylvania, Philadelphia, PA, USA; ${ }^{2}$ Corporal Michael \\ J. Crescenz VAMC, Philadelphia, PA, USA \\ \#These authors contributed equally to this work. \\ Correspondence to: Victoria P. Werth. Department of Dermatology, \\ Perelman Center for Advanced Medicine, Suite 1-330A, 3400 Civic \\ Center Boulevard, Philadelphia, PA 19104, USA. \\ Email: werth@pennmedicine.upenn.edu.
}

Background: Dermatomyositis (DM) is conventionally characterized by interface dermatitis (ID) on skin histopathology. A subset of patients with clinically diagnosed DM have skin biopsies showing spongiotic dermatitis (SD), a histopathology more commonly seen in eczema. Diagnosis of DM is challenging, with significant delays following initial presentation. (I) To identify the percentage of clinically diagnosed DM patients with skin biopsies showing SD, (II) to identify cytokine and cell markers that can determine if a skin biopsy showing SD is consistent with DM in a patient with clinical DM.

Methods: Biopsies from 10 DM patients with SD histopathology were compared to biopsies from 10 healthy controls, 10 patients with eczema, and 12 patients with DM with ID histopathology. Skin biopsies were stained by $\mathrm{H} \& \mathrm{E}$ and by immunohistochemistry for MxA, IFNbeta, CD11c (mDC), and BDCA2 (pDC). Cytokines were quantified by area and intensity. Cells were quantified per HPF. Fisher's exact test was used to compare baseline patient characteristics. One-way ANOVA with Bonferroni's multiple comparison test was used to compare protein expression between groups.

Results: Eleven of $164(6.7 \%)$ patients with a clinical diagnosis of DM at our tertiary care center were identified as having SD. MxA, IFN-beta, CD11c (mDC), and BDCA2 (pDC) protein expression is significantly higher in DM-SD compared to eczema and healthy controls. Expression of MxA, IFN-beta and BDCA2 were not significantly different between DM-SD and DM-ID.

Conclusions: Increased MxA, IFN-beta, CD11c, and BDCA2 protein expression can help distinguish between DM-SD and eczema.

Keywords: MxA; IFN- $\beta$; dendritic cells; spongiotic dermatitis (SD); interface dermatitis (ID); dermatomyositis (DM)

doi: 10.21037/atm.2021.AB017

Open Access Statement: This is an Open Access article distributed in accordance with the Creative Commons Attribution-NonCommercial-NoDerivs 4.0 International License (CC BY-NC-ND 4.0), which permits the noncommercial replication and distribution of the article with the strict proviso that no changes or edits are made and the original work is properly cited (including links to both the formal publication through the relevant DOI and the license). See: https://creativecommons.org/licenses/by-nc-nd/4.0/.

Cite this abstract as: Zeidi M, Chen KL, Patel B, Lim R, Werth VP. Increased dendritic cells and IFN-beta and MxA protein expression in spongiotic dermatitis differentiates dermatomyositis from eczema. Ann Transl Med 2021;9(5):AB017. doi: 10.21037/ atm.2021.AB017 